\title{
Borderland migration, mining and transfrontier conservation: questions of belonging along the Zimbabwe- Mozambique border
}

\author{
Lameck Kachena $\cdot$ Samuel J. Spiegel
}

Published online: 16 July 2018

(C) The Author(s) 2018

\begin{abstract}
Various critiques of transboundary natural resource governance in southern Africa have questioned the efficacy and social equity dimensions of prevailing strategies for protecting transnational ecosystems, highlighting the importance of sociological research on the potentially 'other-ing' impacts of mainstream conservation policy discourse. We draw on research in the Chimanimani Trans-Frontier Conservation Area (TFCA) on both sides of the Zimbabwe-Mozambique border, scrutinizing simplifications inherent in terms such as "illegal foreigners" that obfuscate histories and contemporary realities of cross-border social ties. Engaging perspectives of park authorities and chiefs as well as people who have taken up artisanal mining, we explore two related themes - how 'belonging' is negotiated as well as how conservation agendas are instrumentalized by state and non-state actors. Bringing attention to gaps between policy discourses surrounding TFCAs and territorialized practices of exclusion, the article concludes by calling for greater attention to the mutating significance of colonially established boundaries as
\end{abstract}

L. Kachena

Centre for Applied Social Sciences, University of

Zimbabwe, Harare, Zimbabwe

\section{S. J. Spiegel ( $\square)$}

Centre of African Studies, School of Social and Political Science, University of Edinburgh, Edinburgh, UK

e-mail: sam.spiegel@ed.ac.uk well as the dynamic influences of social networks in borderland spaces.

Keywords Transfrontier conservation - Migration · Belonging $\cdot$ Social networks $\cdot$ Mining $\cdot$ Africa

\section{Introduction}

Transboundary natural resource management (TBNRM) has for many years been a prominent theme in southern Africa, as a notion that seeks to catalyze common strategies for protecting transnational ecosystems and promoting sound development (Wolmer 2003; Hanks 2003; Büscher 2013). One of the main rationales for establishing transboundary resource management initiatives in southern Africa has been that the region's richest and best preserved biodiversity and natural habitats often lie next to national borders-with watershed and wildlife needing protection through collaborative structures (Ramutsindela 2014). However, several critiques have articulated 'fears that border communities, already at the margins of social, political and economic opportunities, will become further isolated through TBNRM initiatives' (Katerere et al. 2001:4). In various parts of Africa, changing patterns of cross-border migration are raising critical concerns about how policymakers address livelihood insecurity in informal economies, rendering notions of transboundary conservation 
exceedingly complex (Andersson et al. 2017). As areas earmarked for borderlands conservation are often characterised by multiple land uses (agropastoralism, tourism, conservation and other activities), changing economic pressures have been reconfiguring how different actors view competing claims, in some cases seeing entrenched patterns of land alienation (Ramutsindela and Sinthumule 2017).

In this article we explore competing claims and social relations in the Chimanimani Trans-frontier Conservation Area (TFCA) along the ZimbabweMozambique border, where migration has long been a strategy in response to economic and political-induced displacements. In the 1990s and early 2000s, work exploring social and cultural dimensions of resource management in the Chimanimani region focused on situations where Mozambicans took refuge on the Zimbabwean side of the border in the face of civil war and forced displacement (McDermott Hughes 2001; Schafer and Bell 2002). Conversely, there was an increased flow of people from Zimbabwe to the Mozambican side of the border due to economic crisis in the mid-2000s (Derman and Kaarhus 2013). Much migration generated what Hammar referred to as 'ambivalent mobilities' (Hammar 2010)—recognizing differentiated perspectives of local communities towards mobile populations as well as diverse emotions experienced by mobile populations. There have been particular concerns about migration in relation to artisanal and small-scale mining-as reflected by condemnations of illegal mining in several newspapers regionally and internationally (Thielke 2008; IRIN 2007). Following the discovery of alluvial gold deposits in 2004 on the foothills of Chimanimani Mountains (including inside the core conservation area of Chimanimani Transfrontier Conservation Area), mining in the region became a last ditch-hope for large numbers of Zimbabwe migrants who faced a deteriorating economic situation (Thielke 2008; Ndunguru et al. 2006; Swradio Report 2007). In the years since, multiple policing campaigns and related control measures have been used in the Chimanimani TFCA by both the governments of Mozambique and Zimbabwe. This resulted, for example, in 52 Zimbabweans detained in 2006 by Mozambican authorities (Ndunguru et al. 2006), although assessments in the mid-2000s often noted that the Mozambican authorities were more laissez-faire when compared with the government approach taken in Zimbabwe (Ndunguru et al. 2006; IRIN 2007). Yet, regardless of how "illegal" or "artisanal" mining is imagined as an economic or ecological force within the TFCA, its sociological dimensions are frequently confounded. While the Southern Africa Development Community (SADC) TFCAs Programme aims to build an inclusive framework that advances the Sustainable Development Goals (including ending poverty in all forms and protecting, restoring and promoting sustainable use of terrestrial ecosystems, sustainably managing forests, combating desertification and halting land degradation and biodiversity loss; SADC 2013, 2015), the limits of inclusivity are often left unclear. We focus in this study on two related themes-how notions of 'foreignness' and 'belonging' are conceived and contested in mining spaces in the Chimanimani TFCA as well as how conservation agendas are instrumentalised by state and non-state actors.

The first section below provides context by examining some of the critical scholarship on conservation schemes in this region, before outlining the methods and approach in our research. The next section explores how social networks and notions of belonging play important roles in accessing natural resources that are significant for livelihoods in the borderland area. We add to debates regarding the meanings of 'belonging' that consider whether people can feel and be treated 'at home across the border' (Madsen and van Naerssen 2003, 3) as well as what Yuval-Davis (2006) refers to as 'the politics of belonging' in contestations around claims based on grounds of origin, culture and citizenship. The article's subsequent section discusses how exclusion/inclusion dynamics in accessing extractive resources relate to conservation discourses invoked by a range of actors including gombiros-a Shona word referring to one who exploits and robs-as well as the discursive framings by environmental officials and non-governmental organisations. We then consider how interdependence sovereignty - the ability of states to control movement and access to resources across borders (Krasner 2001) - is shaped by social networks, underscoring a need to understand transboundary natural resource management projects as entangled in the socio-cultural ambiguities of a hegemonic paradigm profoundly shaped by legacies of colonialism. The article concludes by arguing that the rhetoric of both 'illegality' and 'foreignness' masks shortcomings in contemporary transboundary resource management 
schemes, suggesting future trajectories for research that brings together insights on migration and identity, transfrontier conservation strategy and mining activity in borderlands.

\section{Contextual background and methodological approach}

Measures invoked in the name of preserving biodiversity have long been contentious in southern Africa, where the history and contemporary dynamics of conservation are deeply rooted in colonial legacies (Büscher et al. 2012; Draper et al. 2004; Adams and Mulligan 2003; Van Amerom 2002; Singh and Van Houtum 2002). Protected areas with 'fortress conservation' paradigms have dominated nature preservation schemes for much of the twentieth century and have symbolized different meanings to different people (Hutton et al. 2005). Whilst such paradigms have been invoked as required measures for environmental stewardship, the creation-and enforcement-of protected areas has been contested for contributing to loss of livelihood and legitimacy of populations and for subjugating local and indigenous forms of environmental knowledge by Western scientific constructions of nature (Murombedzi 2003; Brockington and Igoe 2006). Duffy (1997) unpacked how fortress conservation established sets of ostensibly 'incontestable scientific management principles' despite being 'based on politically and ideologically informed decisions' (441). The history of fortress conservation in southern Africa has been widely linked to dispossession, displacements and restricted use of resources fuelling contestations between local people and authorities charged with enforcing conservation laws (Andersson et al. 2017; Lunstrum 2016; Sinthumule 2017; Bluwstein and Lund 2016; Milgroom and Spierenburg 2008).

The Chimanimani TFCA has been recognized as an area of high plant diversity and endemism for more than 50 years (van Wyk and Smith 2001). It is also listed by the Critical Ecosystem Program Fund (BirdLife International 2012) as among the hotspots in the "Key Biodiversity Areas (KBAs)" in the Eastern Afromontane. In 2001, SADC supported the governments of Zimbabwe and Mozambique signing of a Memorandum of Understanding to join the
Chimanimani National Reserve, consisting of $2368 \mathrm{~km}^{2}$ in Mozambique (including both core and buffer zone area), and a $200 \mathrm{~km}^{2}$ core conservation area in the Chimanimani National Park in Zimbabwe. The objectives of the TFCA were centered on conserving the biodiversity of the highlands ecosystem, conserve wildlife, promote tourism and work with communities to develop eco-tourism and sustainable resource harvesting practices (Ghiurghi et al. 2010; SADC 2015). Scholars on the Chimanimani TFCA have noted several developments in fortress conservation approaches as well as alternative paradigms that have offered comparatively less restrictive modes of control on territorial access. According to Dondeyne et al. (2012), the delimitation of community land inside the protected area of the buffer zone in the Chimanimani TFCA (in Mozambique) has been helpful for both handling conflicts and creating partnership between communities and private investors to promote ecotourism. However, scholars also noted that some settlements in the buffer zone are viewed as 'problematic' by both governments and conservation organizations. McDermott Hughes (2001) observed that land alienation connected to ecotourism and conservation projects in Rusitu-Haroni valley (Zimbabwean side of Chimanimani) precipitated conflicts between small-scale farmers and conservation agencies (see also Chidhakwa (2003) for analysis of resource conflicts in relation to the Department of the National Parks and Wildlife Management and the Forestry Commission). Schafer and Bell (2002) further documented power-laden contestations in some of the conservation areas in Chimanimani, arguing that the state can use natural resource management schemes 'as a means to extend its reach in rural areas, rather than devolving control to local communities' (401).

In the mid-2000s new discoveries of gold and diamonds in the area reconfigured the social and economic dimensions of resource extraction in the Chimanimani TFCA. Following the infamous diamond rush in Marange in the eastern region of Zimbabwe, which brought global attention to diamond smuggling routes through the Chimanimani region (Saunders and Nyamunda 2016; Spiegel 2015a), new discoveries within the Chimanimani region drew migration for mineral extraction activity. Mainstream conservation discourse have projected both mobility 
of artisanal miners and panning operations in negative terms, associating these with ecosystem disruption particularly destruction of streams and watersheds (see also Critical Ecosystem Partnership Fund-CEPF-Research Report by Timberlake et al. 2016; Mawere 2011). However, critical research literature elsewhere in Africa has documented the economic and social importance of migration as a way of pursuing limited livelihood opportunities (Bryceson and Jønsson 2010; Jønsson and Bryceson 2009; Nyame and Grant 2014). Notably, Ingram et al. (2011) discussed a conservation/mining nexus along the Congo-Cameroon border, arguing for 'assisting the poorest and socially excluded to practice mining legally' (317), suggesting the importance of a counter-narrative to fortress conservation.

The Chimanimani TFCA has been described recently by SADC as 'one of Africa's least-known nature reserves' (SADC 2015, 1)-likely because other TFCAs, such as the Great Limpopo Transfrontier Conservation Area, have far more famous wildlife attractions with big animals that bring lucrative tourist income. No empirical studies to date have analyzed management plans of the Chimanimani Transfrontier Conservation Area, leaving questions of community engagement and 'belonging' under-theorized in its boundary areas. Accordingly, analysis below draws on research conducted in both the Zimbabwe and Mozambican sides of the border in the Chimanimani District in Manicaland and Sussundenga District of Manica Province, respectively, particularly in five sites (Chikukwa and Ngorima in the conservation area in Zimbabwe; Mahate, Gudza and Nyahezi in the buffer zone in Mozambique), four of which were mining locales including inside the TFCA (Fig. 1).

The research included semi-structured in-depth interviews as well as focus group discussion with 40 migrant artisanal miners (10 migrant artisanal miners in each of the four mining locations) who shared their life experiences. Interviews and in-depth discussions were also held with people from local communities, conservationists, traditional leaders, local authorities and government ministries responsible for mining and conservation. To contextualize longstanding sociocultural and political ties between these communities, our discussions in the five different locales explored how kinship ties and social networks shaped the sense of 'belonging' that facilitated cross-border migration-as well as how the TFCA management strategies have been conceived and contested. As discussed below, some of the particular questions related to the influences of donor funding for the TFCA on the Mozambique side of the border, the influences of Zimbabwean institutions without donor funding on the other side, and the experiences of those deemed 'illegal foreigners' by officials. This paper forms one part of a larger multi-year interdisciplinary project, 'Reconfiguring Livelihoods, Re-Imagining Spaces of Transboundary Resource Management: A Study of Mining and Agency along the ZimbabweMozambique Border,' funded by the UK Economic and Social Research Council (ESRC); the focus here is specifically on questions of belonging and issues of movement in the region.

\section{Seeking livelihoods and cultivating social ties along the border}

There are no jobs but I can mine, farm and trade here. $^{1}$

Miners and representatives from the Chimanimani Rural District Office alike are well aware that complex factors have driven patterns of artisanal mining and mobility. A multitude of protracted economic and political struggles in Zimbabwe have, since the early 2000s, driven mobility of Zimbabweans both towards the Chimanimani border region as well as across the border. Some of the stories we encountered in this research related to the severity of the police crackdowns against artisanal miners in Zimbabwe (especially those launched under Operation Chikorokoza Chapera-'No More Illegal Mining') in the 2006-2008 period-that forced so-called 'foreigners' (artisanal miners from other districts in Zimbabwe) to migrate to the Chimanimani region, searching for difficult-to-reach terrain were policing agents would fail to follow. Some miners focused more on the geological possibilities than the politics. For example, Henry $^{2}$ stated: 'I came here because Chimanimani Area has a variety of mining areas...today I can be mining here (Rusitu, Ngorima) tomorrow in

\footnotetext{
1 Interview, artisanal miner, Rusitu-Ngorima, June 2017.

${ }^{2}$ Interview, migrant artisanal miner, Mt Mawenje, June 2017.
} 
Fig. 1 Study locations in Chimanimani TFCA and surrounding communities. (Adapted by authors from Virtanen (2005))

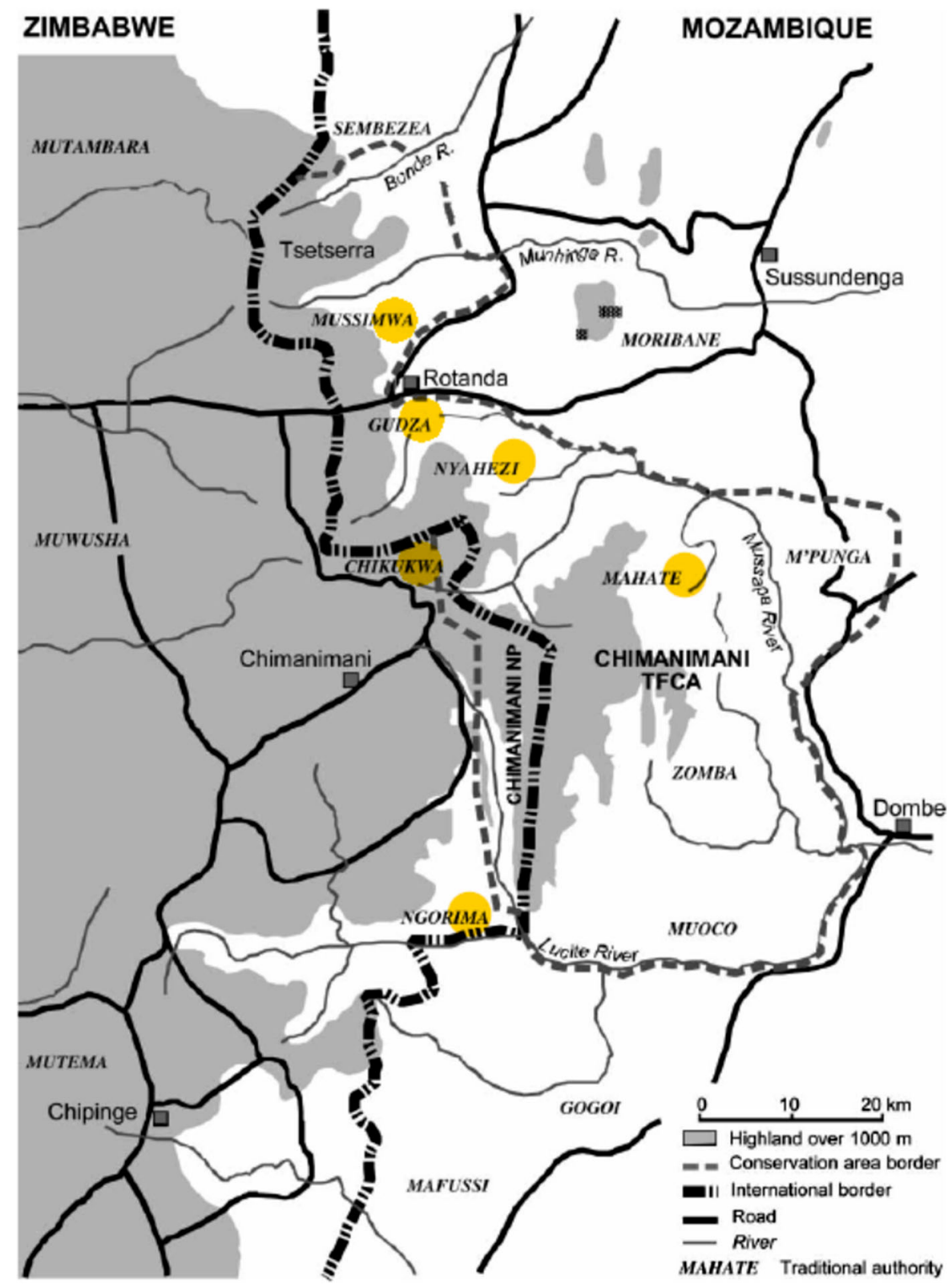

Musanditevera $\left(\mathrm{Mt} \mathrm{Binga}^{3}\right)$...this is why I migrated from Chiredzi. ${ }^{4}$,

Engaging in multiple gold fields is often seen by miners as a resilience mechanism to cope with economic crisis, conflicts and decreasing gold

\footnotetext{
${ }^{3}$ Mt Binga is a mountain located within the TFCA that straddles both countries, though the interviewee here refers to the portion located in Mozambique.

${ }^{4}$ Interview, migrant artisanal miner, Rusitu-Ngorima, June 2017.
}

deposits. Joseph-like other migrant artisanal miners-made it clear that preference is often given for high areas (mountains) rather than commonly known mining fields in order to avoid being raided by intimidating robbers. A traditional leader ${ }^{5}$ likewise reflected that migrant artisanal miners in the Rusitu Valley are occasionally attacked by gombiros $^{6}$ from

\footnotetext{
5 Interview, headman in Ngorima, June 2017.

6 This term in this case refers to local youth mafias.
} 
either Zimbabwe or Mozambique, prompting miners to further encroach in parts of Chimanimani National Park where gombiros rarely invade. ${ }^{7}$ Henry-like other artisanal miners-clarified that he migrated because the region also provides him with other economic opportunities: 'I can do mining, farming and trade because I can move freely across the border'. The Chimanimani region has thus been conceptualized as both a safe haven and a space of possibilities, where moving towards the border-even if not crossing it-has been seen as a way to gain a sense of security.

Environmental discourses in Zimbabwe have been heavily instrumentalised by political authorities to criminalise artisanal miners, some of whom have been told that their criminality is due to non-compliance with environmental impact assessment (EIA) reporting requirements (Spiegel 2017). The matter of TFCAs - like the matter of EIAs-raises questions about the fluid meanings of technical formulations of legitimacy and, as discussed below, becomes a powerful illustration of the politics of belonging. Such politics are elucidated by listening to concerns of migrant artisanal miners, including those on the Mozambican side who carry Zimbabwean identity documentation (ID) cards but are Mozambicans by ethnicity yet not allowed to mine in Mozambique because of a lack of a Mozambican ID. In a wider conceptual discussion, Gilmartin (2008: 1844) poses the question 'Confronted with restrictions, suspicion and hostility, how might migrants address the broader questions of belonging and identity?' As discussed below, in struggles to find livelihood possibilities including accessing extractive resources in the Chimanimani area, migrant artisanal miners have cultivated and resuscitated networks to sustain their existence in the community.

\footnotetext{
$\overline{7}$ A different group of artisanal miners in the area stressed that many mining fields such as Tarka Forest that used to attract artisanal miners are no longer lucrative but 'amaridhabhi' (have been over-mined). A miner operating in Tarka Forest also expressed that 'getting gold is now difficult here...usually it takes me three to 4 days to have few points of gold...the area has been exhausted'.
}

Positioning in the borderland: tensions, claims and social networks

Social ties (through marriage, existing kinship ties, and ethnic belonging) enabled migrant artisanal miners to be integrated into communities and appreciated as part of the community rather as the 'other' - both those who moved closer to the Mozambican border and those who moved across it. To understand the micro-geopolitical dynamics surrounding resource struggles, it is necessary to appreciate how legitimate ownership of land and non-mineral natural resources have been framed by local people-and later used to define access to the extractive resources in the region. One Headman stated that 'gold was discovered in our land here in Chimanimani Area and therefore access should be for those who own land under which gold was discovered. ${ }^{8}$ The gold discovery was also understood through the spiritual lens; Chief Chikukwa attributed gold discovery as a gift from ancestors to relieve the people in Chimanimani from deep poverty of that time (referring to the 2008 economic crisis). ${ }^{9}$ In his account, the gold discovery was meant to benefit people with Chimanimani identity-those who belonged in the area as locals.

Land ownership claims can be attached to various combinations and bundles of rights that may change over time (Ribot and Peluso 2003; Schlager and Ostrom 1999). In Chikukwa, the rights of community members were emotively linked to land claims and directly defined eligibility to control and access gold deposits. Narratives in some local communities framed cross-border migration as a threat that impinges on local rights to the gold fields, instigating notions of exclusion. As stated by a Headman it is impossible for us as owners of land to fold our hands and allow our resources to benefit the foreigners.' ${ }^{10}$ Connected to this thinking, some local communities leveled blame against Shurugwi artisanal miners for causing fear, insecurity and disorder, as well as alleging foreigner involvement in robbing and murdering local miners. According to Chief Chikukwa, his counterpart, Chief Ngorima, was bitten by Shurugwi artisanal miners when he tried to prevent them from

\footnotetext{
$\overline{8}$ Interview, Village Head, Ngorima, June 2017.

9 Interview, Chief Chikukwa, Chikukwa, July 2017.

${ }^{10}$ Focus group discussion, traditional leaders, Vhimba, Ngorima, July 2017.
} 
mining near sacred shrines. ${ }^{11}$ As a result, local youth groups were formed to chase migrant artisanal miners from Shurugwi; as one traditional leader expressed, 'we did our own operation on maShurugwi dzokerai kumba (migrant Shurugwi miners go back to your home area). ${ }^{12}$

However, reflections from migrant artisanal miners confirmed that crackdowns against Shurugwi migrants were also extended to all migrant miners irrespective of community of origin. Such tensions led migrant artisanal miners to attempt to formulate or rekindle strong social relationships with local people-including traditional leaders, gold dealers and police officials-cognizant that the dynamics of forming social capital through kinship ties, ethnic belonging and language skills constitute necessarily important determinants of access to local resources owned by local inhabitants (Bourdieu 2011; Schoenberger and Turner 2008). A migrant artisanal miner from Chipinge explained that his close relationship to police officers-who are maintaining order in the mining fields-spared him from attack. ${ }^{13}$ Thus, to have access to gold, migrant artisanal miners have been nurturing social networks with local people, also enabling them to access land on which to settle, thereby becoming locals rather than foreigners. A migrant miner from Gokwe explained how he was shielded from the attacks targeted to foreigners by his father's friend who integrated him in his family and later assisted him to acquire land. ${ }^{14}$ Social ties were also forged by migrant miners by tracing kinship or by intermarriages; one miner from Chiredzi acknowledged acquiring land in Vhimba Community two years after marrying the Village head's daughter proudly noting that he is now part of the royal family. ${ }^{15}$ Another migrant miner from Masvingo-a region that shares ethnic ties with Shurugwi-explained that his uncle (mother's brother) protected him

\footnotetext{
11 Interview, Chief Chikukwa, Chikukwa Community, July 2017.

12 Focus group discussion, traditional leaders, Muchadziya, Ngorima, July 2017.

${ }^{13}$ Interview, migrant artisanal miner from Chipinge, Mt Mawenje-Chimanimani National Park, July 2017.

14 Interview, migrant artisanal miner from Gokwe, Haroni River-Ngorima, June 2017.

15 Interview, migrant artisanal miner from Chiredzi, Tarka Forest-Ngorima, June 2017.
}

by incorporating him into a mining syndicate. ${ }^{16}$ To reinforce their newly acquired identity, migrant miners adopted local language skills that were critical for communicating with locals from both sides of the border. For example a migrant artisanal miner from Bocha (Zimbabwe) stated that 'I survived the fierce operation maShurungwi dzokerai kumba (targeting migrants) because I mimicked the chiNdau dialectic to hide my identity...this even helped me when I crossed to mining areas in Mozambique or worked with artisanal miners from Mozambique who could not speak English ${ }^{17}$.

Stories on the Mozambican side also stressed that social networks were highly valuable to obtain mining tools. For example, migrant artisanal miners from distant communities in Zimbabwe rely on their syndicate members (in local Mozambican miner groups) to retrieve tools after occasional raids by Chimanimani National Reserve Rangers. A migrant artisanal miner from Bocha in Zimbabwe explained that his reputation and experience in panning enables him to form new syndicates with local miners ${ }^{18}$ underscoring the symbiotic nature of the relationship in which Mozambican miners learnt mining skills from migrant artisanal miners from Zimbabwe who joined their syndicates. ${ }^{19}$

We are Zimbabweans, we are Mozambicans

Territorial identities, critical in shaping eligibility in accessing or controlling natural resources-particularly gold deposits in the region, relate not only to becoming "local" but also being historically linked to "local". The longstanding ties between communities in Mozambique and Zimbabwe provide a compelling rationale for seeking refuge or alternative living space when displaced. Ethnic ties across the MozambiqueZimbabwe boundary were well illustrated by Chief Gudza who recounted that his chieftainship was originally from the Mbire District, across the border. ${ }^{20}$

\footnotetext{
${ }_{16}$ Interview, migrant artisanal miner from Masvingo, Mt Mawenje-Ngorima, June 2017.

${ }^{17}$ Interview, migrant artisanal miner from Bocha in Vhimba Community, June 2017.

${ }^{18}$ Interview, migrant artisanal miner Mt Peza, Gudza, July 2017.

${ }^{19}$ Interview, headman in Gudza, July 2017.

${ }^{20}$ Interview, Chief Gudza-Mozambique, July 2017.
} 
One village head under Chief Mahate expressed that his community is more linked to communities on the Zimbabwe side of the border than those outside the Chimanimani region in Mozambique ${ }^{21}$ - a sentiment echoed by other chiefs. ${ }^{22}$ As discussed elsewhere by Eilenberg and Wadley (2009), borders imposed by colonial rule artificially partition ethnic groups that transcend the territorial line of the state, obscuring how kinship ties and cultural identities can be crucial in cross-border migration. In the Chimanimani area, the long history of migration, and relationships between identity, place and mobility, condition notions of belonging that contest the categorization of migrants as 'others' without rights and entitlements.

Dual attachment to Zimbabwe and Mozambique in the Chimanimani region has often been revived as a response to various waves of displacement in different epochs. Movement from Mozambique to Zimbabwe was first invoked during colonial times when there were few economic opportunities in the Mozambican side as compared to the Zimbabwean side. A headman in Gudza Community explained that his father left Mozambique in 1965 to work in tea estates in Chipinge District as there were fewer employment opportunities for Blacks in Mozambique during the Portuguese rule as compared to Rhodesia (Zimbabwe), ${ }^{, 2}$ noting that although his family migrated back after staying for 25 years in Chipinge, his two sisters remained on the Zimbabwean side. Other traditional leaders in both Zimbabwe and Mozambique shared similar stories. A village head stated that 'during colonial time Chimanimani region (Mozambique) was poorly developed there were no roads, clinics, schools and markets people used to depend on the Zimbabwe side for services...I recall when my late father who was the headman writing travel passes for Mozambicans who wanted to sort for employment in urban areas in Zimbabwe side. ${ }^{24}$ Sharing a common language $\left(\mathrm{chiNdau}^{25}\right)$ was critical in shaping a 'ndauness' identity (Patrício 2012) which is

$\overline{21}$ Interview, Village Head in Mahate-Mozambique, July 2017.

${ }^{22}$ Focus group discussion Chikukwa community-Zimbabwe, July 2017.

23 Key informant interview, Village Head in Gudza, July 2017.

24 Interview, Village Head in Ngorima-Zimbabwe, June 2017.

25 A Shona dialectic shared by communities (including Chimanimani region) in central Mozambique and southeastern Zimbabwe. facilitating cross border movements in the region. Chief Mahate stated that 'both communities in Zimbabwe and Mozambique speak chiNdau...this keeps us together and it makes movement to Zimbabwe simple...one will be able to present himself/herself in a culturally acceptable way when crossed the border. ${ }^{26}$ Mobility of people from Mozambique to Zimbabwe was further increased in the post-colonial time when the country was affected by a civil war. Gorongosa National Reserve and Chimanimani forests—including Moribane Forests-harbored RENAMO $^{27}$ guerillas leading to multiple displacements of local people by FRELIMO ${ }^{28}$ soldiers during the civil war. ${ }^{29}$ Given the multiple confrontations that were unfolding in the Mozambican side, many Mozambicans in the Chimanimani region made Zimbabwe their new home.

However, due to the economic and political crises that unfolded in Zimbabwe in the mid-2000s, Mozambicans overwhelmingly found limited opportunities. The difficulties in surviving in Zimbabwe for Mozambican migrants who were displaced by economic challenges, droughts and civil war, led many to reassert their 'belonging' to Mozambique using an ethnicity lens in order to migrate back to Chimanimani (Mozambique). A Chimanimani Lands Officer noted that during Zimbabwe's land reform program very few Mozambican migrants were able to obtain land even if they held a Zimbabwean identity card. ${ }^{30}$ Chief Nyahezi also expressed that several Mozambicans who stayed in the Zimbabwean side even for more than 30 years migrated back here (Chimanimani) to look for land, having failed to compete for land during 'hondo yeminda kuZimbabwe' (the violent land reform in Zimbabwe). ${ }^{31}$ As one artisanal miner stated:

I was born here in Mozambique but migrated to Zimbabwe when I was only five years in the late1970s...I went to school in Zimbabwe...I have a

\footnotetext{
${ }^{26}$ Interview, Chief Mahate- Mozambique, July 2017.

27 The Mozambique Resistance Movement (RENAMO) that was funded by the Rhodesian Government to destabilize Mozambique Independence.

28 The national armed forces for the Mozambique ruling party, Front for Liberation of Mozambique (FRELIMO).

29 Interview, Chief Nyahezi-Mozambique, July 2017.

30 Interview, Chimanimani Lands Officer, July 2017.

31 Interview, Chief Nyahezi, July 2017.
} 
Zimbabwean identity card and I came here in the early-2000s to burry my father...but when I went back to Zimbabwe afterwards...the tea estate I was working for was grabbed for land redistribution...I decided to come back here where I buried my father...I belong here and my ancestral spirits are here. ${ }^{32}$

Descendants of Mozambican migrants from his community who were in Zimbabwe returned, especially those embracing their ethnic and kinship ties. ${ }^{33}$ However, unlike in the Zimbabwean Chimanimani region as well as other communal areas in Mozambique where distribution of land to migrants is conducted solely by customary institutions, a centralized institutional framework has been adopted in the Chimanimani buffer zone. A Chimanimani National Reserve Community Officer exposed the fact that to avoid unsustainable encroachment, village heads are compelled to submit names of land seekers - foreign or local-and the size of land to be distributed, then conduct physical assessments before (dis)approving. ${ }^{34}$ This produces forms of disenfranchising local people from natural resources to which they have had traditional access, contradicting TFCA rhetoric of 'strengthening' communities to secure proprietorship over natural resources in order to be motivated to manage them sustainably.

The notion of citizenship is also used to deny migrants access to community resources and opportunities. A group of migrants revealed that they are destitute and artisanal mining is the only alternative because state and non-state actors (Chimanimani National Reserve and MICAIA Foundation) excluded them from working in seasonal jobs offered to other local community members-as they did not possess Mozambican identity cards. ${ }^{35}$ Similar exclusion was also cited by a migrant miner from Chikukwa who stated that the 'MICAIA Foundation never gave me seeds or a beehive because I do not have a Mozambican National Identity Card which they require for registration, but I cannot go back to Zimbabwe, so

\footnotetext{
32 Interview, Mozambican miner who returned from Zimbabwe, Mt Peza-Mozambique, July 2017.

33 Interview Chief Gudza, July 2017.

${ }^{34}$ Interview, July 2017.

35 Focus group discussion, Mt Peza, July 2017.
}

instead I mine here. ${ }^{36}$ Meanwhile, on the other side of the border, a migrant artisanal miner from Mozambique stated that 'I stay here in Muchadziya [Zimbabwe] with my grandmother whilst doing mining...I cannot sell my gold to Fidelity Printers and Fineries because I do not have a Zimbabwean identity card...so I had to pay a middleman to sell for me. ${ }^{37}$ Another migrant artisanal miner from Dombe in VhimbaNgorima revealed that he is forced to sell his gold in Chimio-Mozambique instead of Mutare-Zimbabwe because the gold dealers in Zimbabwe threaten to report him to the police if he failed to agree to sell them his gold for the lowest price they offer. ${ }^{38}$

Traditional leaders in both countries confirmed that it is possible for a Mozambican or Zimbabwean migrant to obtain an ID card with the help of relatives. However, stories of migrant miners who have gone through the process of obtaining IDs in both countries expressed that it is cumbersome and unaffordable. A migrant artisanal miner (from Zimbabwe-Chipinge District) who also was working as a part time cattle herder in Mahate village Mozambique) stated:

The process is long-it can take more than a month in Mozambique...the Registry Officers in Sussundenga District instructed me to first acquire a birth certificate which I failed to obtain because I could not meet the requirements... They wanted me to bring two family witnesses which I did and a letter from the local administrator (that confirms that I am part of the village)...It was hard to get the letter...The administrator worked with Chimanimani National Reserve guards to criminalize us. ${ }^{39}$

Mpunga Community Administrator reasoned that they always conduct rigorous vetting before writing a confirmation letter for people with a vague background in the community because the region is a target of RENAMO security agents. Migrant miners in Zimbabwe indicated that fees charged to obtain an identity card are exorbitant. A migrant miner from Dombe-Mozambique who is living in Ngorima-

\footnotetext{
$\overline{36}$ Interview, artisanal miner, Mt Peza, July, 2017.

37 Interview, migrant artisanal miner from Mahate-Mozambique, Ngorima, July 2017.

38 Interview, migrant artisanal miner Mt Mawenje-Ngorima.

39 Interview, migrant artisanal miner (also working as a cattle herder) Mpunga Community.
} 
Zimbabwe revealed that in January 2014 he obtained his ID card but the process was very expensive for him. He stated that he had to pay US\$5.00 to the village head to write a letter of support that explained why he does not hold a birth certificate; he was asked to pay a penalty fee of US\$ 20.00 by the registry office to obtain a birth certificate and an identity card (Chimanimani District); and he then had to pay the Registry Official 'a bribery token of US $\$ 15.00$ to process the documents '(birth certificate and ID) within a day. ${ }^{40}$

The above struggles by migrant artisanal miners in the region are indicative of exclusionary practices by state actors who invoke notions of citizenship to address perceived threats to the protection of the transfrontier conservation zone. Counterproductively, such restrictive measures have been undermining the transboundary objectives espoused by the state ostensibly aiming to both reunite communities divided by borders and allow mobile peoples to move across their traditional territories more easily. Additionally, as explored further below, critical reflection is needed on imbalances that are (re)produced when conservationists apply an agrarian-oriented livelihood lens that naively sidelines viable non-farm livelihoods such as artisanal mining, which supports rural economies throughout Sub-Saharan Africa including Zimbabwe and Mozambique (Huggins et al. 2017; Hilson and Maconachie 2017; Dondeyne et al. 2009).

\section{Conservation discourse and exclusion}

Various networks of state and non-state actors, with diverse motives for regulating people in the TFCA, have long shaped negative views about migrant miners. In the early years of gold discovery in the TFCA region, coercive measures in Zimbabwe were part of a countrywide crackdown called Operation Chikorokoza Chapera, ostensibly to bring 'sanity' and end 'illicit' activities (Spiegel 2009, 2014, 2015b). Although environmental protection discourse figured prominently to rationalize these actions, these masked other economic interests by elite actors and resulted in a range of unregulated mining activities within the TFCA. In Mozambique a joint force of military and

\footnotetext{
${ }^{40}$ Interview, migrant artisanal miner from Dombe (Mozambique) living in Ngorima Community.
}

police was dispatched in the region between 2009 and 2012 - a reversal from the previous leniency of the Mozambican Government towards this activity and a noticeable contradiction to the advice of Ndunguru et al. (2006) who had warned that past law enforcement initiatives in Chimanimani had created conditions for corruption and abuses while resulting in "more scattered patterns of mining, rather aggravating the environmental impact" (p. 19). A Ministry of Agriculture and Rural Development representative argued that evicting artisanal miners was necessary to reverse the loss of biodiversity resulting from RENAMO guerilla encroachment in protected areas in Mozambique-including in the current Chimanimani $\mathrm{TFCA}^{41}$; and recently 10 Tanzanian artisanal miners were fined US\$16.000 for mining in the Niassa National Park area (All Africa 2017). Yet, miners interviewed in our study argued that aggressive law enforcement came as a shock and created livelihood difficulties without effectively stopping mining.

In Mozambique, a World Bank Project in the Chimanimani National Reserve attempted to shift communities in the buffer zone away from artisanal mining (in 2015), ${ }^{42}$ in keeping with one of the central goals of the TFCA, namely to promote sustainability by championing conservation agriculture as an alternative livelihood. ${ }^{43}$ Funding not only included resources and technical support to police artisanal mining within the buffer zone and core conservation area, but also to distribute beehives, tools (hoes, picks, exes, hoes, and shovels), seeds, training and market linkages to encourage adoption of less environmentally destructive livelihoods. ${ }^{44}$ However, this World Bank initiative has received criticism for several reasons, including its narrow approach to integrating economic concerns. ${ }^{45}$ An insider involved in the Chimanimani National Reserve dismissed the "alternative livelihoods" solutions promoted by the World Bank project—referring to conservation agriculture as

\footnotetext{
${ }^{41}$ Interview, Ministry of Rural and Agriculture in Sussendanga District Officer, July 2017.

42 Interview, Ministry of Agriculture and Rural Development, Suusendaga District, July 2017.

43 Chimanimani Transfrontier Conservation Area Memorandum of Understanding (2003).

44 Interview, MICAIA Foundation Field Officer, July 2017.

45 Interview, Chimanimani National Community Engagement Officer, July 2017.
} 
unattractive to some communities. A traditional leader explained: 'the whole community cannot do beekeeping ... who would accept to grow beans (conservation agriculture) instead of artisanal mining which brings quick return? ${ }^{46}$ A village head also revealed that some households are actually selling the tools they get from the MICAIA Foundation to artisanal miners in Musanditeera or are using them in artisanal mining themselves. ${ }^{47}$ Ministerial concerns were more focused on the time frame; a Ministry of Rural and Agriculture representative added that the World Bank funding is ending in 2019 and is too short for meaningful economic development and meaningful community participation. ${ }^{48}$ Similarly, Anderson et al. (2017) studying the Zimbabwe-Mozambique-Zambia Transfrontier Conservation Area (ZIMOZA) after the withdrawal of International Union for Conservation of Nature (IUCN) observed that local participation ceased-and lack of visible economic gains from projected ecotourism pushed local communities to overharvesting of natural resources. Brockington (2004) also showed that communities may undermine the establishment of a protected area by continuing to hunt, fish, log, farm, burn or embark other banned activities inside protected areas. In the Chimanimani context, rejection of donor-prescribed 'alternative livelihoods' projects can also be understood as related to what Scott (2008) termed 'weapons of the weak' whereby 'powerless groups' use any means to resist unrealistic rules imposed by governments or nongovernmental organisations.

On another note, the World Bank funding is creating frictions in the management of Chimanimani TFCA between Zimbabwe and Mozambique. A Chimanimani National Park Officer interviewed in Zimbabwe lamented that the World Bank funding is only to Mozambique and not to Zimbabwe, noting that the project portrays the Zimbabwean side as weak and without concern about the problems linked to artisanal mining. ${ }^{49}$ The Chimanimani Rural District Officer further dismissed the very existence of the Chimanimani TFCA stating "we cannot say we have a TFCA

\footnotetext{
$\overline{46}$ Interview, Chief Nyahezi, July 2017.

47 Interview, Village head Mahate Community, July 2017.

48 Interview, Ministry of Agriculture and Rural Development, Chimoio, July 2017.

49 Interview, Chimanimani National Park Management, August 2017.
}

here whilst one side only is getting funding...how we can participate in some of the initiatives?" Reflecting a theme that is also poignant in transboundary resources management and community development discourse elsewhere, namely the imbalance between the environmental and the social, he furthermore stated: "the problem of the TFCA is not about artisanal miners but of the future of communities in the buffer zone in the Mozambique side; they need social facilities such as schools and clinics to manage population growth and livelihoods based on education." 50

Finally, for some people in the Chikukwa community, the environmental protection rationale for ceasing artisanal resource extraction seemed rather hollow as they were denied access to mining areas allegedly because of concerns for environmental degradation while a large diamond company was given access to mine areas adjacent to the Chimanimani TFCA. Specifically, a local Chief recounted that in 2006 when the Rural District Council of Chimanimani tried to formalize artisanal miners in the area, his community was promised mining claims but this never materialized allegedly because the area was adjacent to the Chimanimani TFCA, yet a large company DTZOZGEO (Pvt) Limited ${ }^{51}$ was given a permit to mine diamonds in the same region. ${ }^{52}$ Meanwhile, contentious environmental discourses were also invoked by authorities as key rationales to police artisanal miners in Mt Mawenje who, in turn, were furious over the harassment and fines charged by Community Based Natural Resource Management (CBNRM) committees and Environmental Management Agency (EMA). An artisanal miner explained that when he was caught mining by EMA in 2015 he was threatened with 5 years in jail if he could not pay the fine. ${ }^{53}$ Such experiences of 'conservation governance', seemingly inconsistent and mimicking colonial regimes of coercion and punishment, reflect how contemporary regimes for controlling protected areas have resulted in ultimatums, intimidation, rent seeking and fear

\footnotetext{
${ }^{50}$ Interview, Chimanimani Rural District, July 2017.

51 A joint-venture mining company owned by Development Trust Zimbabwe and Russian company Econedra Limitedduring time of the study its operation was suspended by the Government of Zimbabwe.

52 Focus group discussion Chikukwa Community, July 2017.

53 Interview, artisanal miner, Mt Mawenje, July 2017.
} 
rather than sustainable solutions. While in theory environmental stewardship goals could be embraced widely, these perspectives point to an extension of power that fits into established patterns of "articulating sovereignty" in the name of conservation (Lunstrum 2013) where modes of territorial and population control ultimately entrench uneven patterns of exclusion based on a discourse of non-belonging. Contradictory to the initial notion that TFCAs could become opportunities for equitable local development, the persistence of the above tensions also reflect how the real-world uses of notions of transfrontier conservation have led to forms of environmentalism that are simultaneously ineffective in ecological terms and perceived as unjust.

\section{Conclusion}

The quest for a model for biodiversity conservation that promotes cooperation-and that could replace the legacies of conflict and fortress conservation in southern Africa-has led both regional policymakers and foreign donors to champion transboundary natural resource governance as a solution (Barquet et al. 2014). The rationality brought forward is that transboundary conservation areas can resuscitate local economic development whilst maintaining sustainable natural resources management (Draper et al. 2004). The southern Africa region has become aligned to the new global conservation priority of 'people and parks', which developed in the wake of the Bali declaration of 1982, that protected areas should 'serve human society' (Carruthers 1997). However, our analysis of the region leads us to argue that the concept of transboundary people-parks joins other abstractive development concepts such as 'sustainable development', 'community ownership' and 'good governance', which share a similar all-encompassing motivational purpose (Van Amerom and Büscher 2005) but can be simplistic and contradictory in its implementation. This article illustrated that the Chimanimani transboundary conservation project, though premised on local development through regional collaboration, has been embedded in processes of restricting livelihoods and decision-making opportunities, while advancing practices that gloss over kinship ties and a historical sense of belonging. Although serious environmental concerns bring together state and non-state actors in Chimanimani, the discourse is currently manipulated to restrict participation in resource management through employing practices that appear to many as inconsistent and unfair. Gaps between policy discourses surrounding TFCAs and territorialized practices of exclusion highlight the need for attention to how prevailing models are ineffective and how people in border zones adapt in the face of challenges, with uneven results.

This article illustrates that the concept of free border movement is a far-fetched idea in this transboundary conservation area, with multiple access constraints and evictions of migrant artisanal miners in both Zimbabwe and Mozambique in ways often perceived to ignore kinship ties and historical realities. In Chimanimani, the territorial border, instrumantalized to reinforce citizenship identity as an exclusionary weapon to regulate mobility flows, reproduced forms of alienation that have led to 'belonging' dilemmas among local and foreign artisanal miners, confounded by historical identities that transcend political boundaries. This therefore brings us to the current debates on the politics of belonging — who has power to define who can belong? And what are the conditions (Delanty et al. 2008) - as a dialectal construct - that can be invoked for either socio-spatial inclusion or exclusion? In re-imagining the politics of transboundary conservation areas, the article challenges future researchers not only to entertain questions regarding the sustainability and viability of alternatives to 'illegal' livelihoods such as artisanal mining, but also to rethink the exclusionary notion of 'foreignness' in considering how the mobilities of people in TFCAs are shaped by kinship, ethnic and historical ties that must be recognized.

Acknowledgements We would like to express thanks to all the people who participated in this research. This research was possible due to financial support from the UK Economic and Social Research Council (ESRC), for which we are also grateful.

Funding The study was funded by the Economic and Social Research Council (ESRC) in the UK, from an ESRC Future Research Leader Award that Dr. Spiegel received for this research project.

\section{Compliance with ethical standards}

Conflict of interest We confirm that the article has conformed to all ethical standards. There are no conflict of interest. 
Informed consent Informed consent was provided by participants, consistent with all appropriate protocols.

Open Access This article is distributed under the terms of the Creative Commons Attribution 4.0 International License (http:// creativecommons.org/licenses/by/4.0/), which permits unrestricted use, distribution, and reproduction in any medium, provided you give appropriate credit to the original author(s) and the source, provide a link to the Creative Commons license, and indicate if changes were made.

\section{References}

Adams, W., \& Mulligan, M. (Eds.). (2003). Decolonizing nature: Strategies for conservation in a post-colonial era. London: Earthscan.

All Africa. (2017). Mozambique: Illegal miners to be deported to Tanzania. 18 August. http://allafrica.com/stories/ 201708190009.html.

Andersson, J., de Garine-Wichatitsky, M., Cumming, D., Dzingirai, V., Giller, K. (Eds.). (2017). Transfrontier conservation areas: People living on the edge. Boca Raton: Taylor and Francis.

Barquet, K., Lujala, P., \& Rød, J. (2014). Transboundary conservation and militarized interstate disputes. Political Geography, 42, 1-11.

Bluwstein, J., \& Lund, J. (2016). Territoriality by conservation in the Selous-Niassa corridor in Tanzania. World Development, 101, 453.

Bourdieu, P. (2011). The forms of capital (1986). Cultural Theory: An Anthology, 1, 81-93.

Brockington, D. (2004). Community conservation, inequality and injustice: Myths of power in protected area management. Conservation and Society, 2(2), 411-432.

Brockington, D., \& Igoe, J. (2006). Eviction for conservation: A global overview. Conservation and Society, 4, 424.

Bryceson, D., \& Jønsson, J. (2010). Gold digging careers in rural East Africa: Small-scale miners' livelihood choices. World Development, 38, 379-392.

Büscher, B. (2013). Transforming the frontier: Peace parks and the politics of neoliberal conservation in Southern Africa. Durham: Duke University Press.

Büscher, B., Sullivan, S., Neves, K., Igoe, J., \& Brockington, D. (2012). Towards a synthesized critique of neoliberal biodiversity conservation. Capitalism Nature Socialism, 23, 4-30.

Carruthers, J. (1997). Nationhood and national parks: Comparative examples from the post-imperial experience. Ecology and Empire: Environmental History of Settler Societies, 1, 125-138.

Chidhakwa, Z. (2003). Managing conflict around contested natural resources: A case study of Rusitu Valley area, Chimanimani, Zimbabwe. Natural Resource Conflict Management Case Studies: An Analysis of Power, Participation and Protected Areas, 1, 183.

Delanty, G., Wodak, R., \& Jones, P. (Eds.). (2008). Identity, belonging and migration. Oxford: Oxford University Press.

Derman, B., \& Kaarhus, R. (Eds.). (2013). In the shadow of a conflict: Crisis in Zimbabwe and its effects in Mozambique,
South Africa and Zambia. Benin City: African Books Collective.

Dondeyne, S., Kaarhus, R., \& Allison, G. (2012). Nature conservation, rural development and ecotourism in central Mozambique: Which space do local communities get? In I. Convery, G. Corsane, \& P. Davis (Eds.), Making sense of place. Suffolk: Boydell Press.

Dondeyne, S., Ndunguru, E., Rafael, P., \& Bannerman, J. (2009). Artisanal mining in central Mozambique: Policy and environmental issues of concern. Resources Policy, 34(1), 45-50.

Draper, M., Spierenburg, M., \& Wels, H. (2004). African dreams of cohesion: Elite pacting and community development in transfrontier conservation areas in Southern Africa. Culture and Organization, 10, 341-353.

Duffy, R. (1997). The environmental challenge to the nationstate: superparks and national parks policy in Zimbabwe. Journal of Southern African Studies, 23(3), 441-451.

Eilenberg, M., \& Wadley, R. L. (2009). Borderland livelihood strategies: The socio-economic significance of ethnicity in cross-border labour migration, West Kalimantan, Indonesia. Asia Pacific Viewpoint, 50(1), 58-73.

Ghiurghi, A., Dondeyne, S., \& Bannerman, J. (2010). Chimanimani national reserve management plan. Maputo: Ministry of Tourism.

Gilmartin, M. (2008). Migration, identity and belonging. Geography Compass, 2(6), 1837-1852.

Hammar, A. (2010). Ambivalent mobilities: Zimbabwean commercial farmers in Mozambique. Journal of Southern African Studies, 36, 395-416.

Hanks, J. (2003). Transfrontier conservation areas in Southern Africa. Journal of Sustainable Forestry, 17, 127-148.

Hilson, G., \& Maconachie, R. (2017). Formalising artisanal and small-scale mining: Insights, contestations and clarifications. Area, 49, 443-451.

Huggins, C., Buss, D., \& Rutherford, B. (2017). A 'cartography of concern': Place-making practices and gender in the artisanal mining sector in Africa. Geoforum, 83, 142.

Hutton, J., Adams, W., \& Murombedzi, J. (2005). Back to the barriers? Changing narratives in biodiversity conservation. Forum for Development Studies, 32, 341-370.

Ingram, V., Tieguhong, J. C., Schure, J., Nkamgnia, E., \& Tadjuidje, M. H. (2011). Where artisanal mines and forest meet: Socio-economic and environmental impacts in the Congo Basin. Natural Resources Forum, 35, 304-320.

IRIN. (2007). Gold fever infects young and old. http://www. irinnews.org/feature/2007/05/02/gold-fever-infectsyoung-and-old. Accessed 14 Nov 2017.

Jønsson, J. B., \& Bryceson, D. F. (2009). Rushing for gold: Mobility and small-scale mining in East Africa. Development and Change, 40, 249-279.

Katerere, Y., Hill, R., \& Moyo, S. (2001). A critique of transboundary natural resource management in Southern Africa. Harare: IUCN Regional Office.

Krasner, S. (2001). Abiding sovereignty. International Political Science Review, 22(3), 229-251.

Lunstrum, E. (2013). Articulated sovereignty: Extending Mozambican state power through the Great Limpopo Transfrontier Park. Political Geography, 36, 1-11. 
Lunstrum, E. (2016). Green grabs, land grabs and the spatiality of displacement: Eviction from Mozambique's Limpopo National Park. Area, 48, 142-152.

Madsen, K. D., \& Van Naerssen, T. (2003). Migration, identity, and belonging. Journal of Borderlands Studies, 18, 61-75.

Mawere, M. (2011). Gold panning in central Mozambique: A critical investigation of the effects of gold panning in Manica Province. International Journal of Politics and Good Governance, 2(24), 0976-1195.

McDermott Hughes, D. (2001). Cadastral politics: The making of community-based resource management in Zimbabwe and Mozambique. Development and Change, 32, 741-768.

Milgroom, J., \& Spierenburg, M. (2008). Induced volition: Resettlement from the Limpopo National Park. Mozambique. Journal of Contemporary African Studies, 26(4), 435-448.

Murombedzi, J. (2003). Pre-colonial and colonial conservation practices in southern Africa and their legacy today. Gland: IUCN.

Ndunguru, E., Dondeyne, S., \& Mulaboa, J. (2006). Illegal gold mining in the Chimanimani National Reserve: Environmental and socio-economic assessment. Ministry for the Coordination of Environmental Action, Chimoio. https:// www.communitymining.org/attachments/263_Illigal\% 20gold\%20mining\%20in\%20Chimanimani\%20NR_2007. pdf. Accessed 14 Nov 2017.

Nyame, F., \& Grant, J. (2014). The political economy of transitory mining in Ghana. Extractive Industries and Society, $1,75-85$.

Patrício, M. (2012). Living in the Mugano-the partitioned Ndau in the Mozambique-Zimbabwe borderland. In Proceedings 22nd annual conference of the ASEN.

Ramutsindela, M. (2014). Cartographies of nature: How nature conservation animates borders. Cambridge: Cambridge Scholars Publishing.

Ramutsindela, M., \& Sinthumule, I. (2017). Property and difference in nature conservation. Geographical Review, 107, 415-432.

Ribot, J., \& Peluso, N. (2003). A theory of access. Rural Sociology, 68, 153-181.

SADC. (2013). Transfrontier conservation areas in Southern Africa. http://www.sadc.int/files/4614/2122/3338/SADC_ TFCA_Programme_FINAL_doc_Oct_2013.pdf. Accessed 14 Oct 2017.

SADC. (2015). Chimanimani transfrontier conservation area. https://www.giz.de/en/downloads/giz2015-en-tfcachimanimani.pdf. Accessed 7 Sept 2017.

Saunders, R., \& Nyamunda, T. (Eds.). (2016). Facets of power: Politics, profits and people in the making of Zimbabweís Blood Diamonds. Harare: Weaver Press.

Schafer, J., \& Bell, R. (2002). The state and community-based natural resource management: The case of the Moribane Forest Reserve, Mozambique. Journal of Southern African Studies, 28, 401-420.

Schlager, E., \& Ostrom, E. (1999). Property rights regimes and coastal fisheries. In M. D. McGinnis (Ed.), Polycentric governance and development. Ann Arbor: University of Michigan Press
Schoenberger, L., \& Turner, S. (2008). Negotiating remote borderland access: Small-scale trade on the VietnamChina Border. Development and Change, 39, 667-696.

Scott, J. C. (2008). Weapons of the weak: Everyday forms of peasant resistance. New Haven: Yale Press.

Singh, J., \& Van Houtum, H. (2002). Post-colonial nature conservation in Southern Africa: Same emperors, new clothes? GeoJournal, 58(4), 253-263.

Sinthumule, N. I. (2017). Resistance against conservation at the South African section of Greater Mapungubwe (Trans)frontier. Africa Spectrum, 52, 53-77.

Spiegel, S. J. (2009). Resource policies and small-scale gold mining in Zimbabwe. Resources Policy, 24(1-2), 39-44.

Spiegel, S. J. (2014). Legacies of a nationwide crackdown in Zimbabwe: Operation Chikorokoza Chapera in gold mining communities. Journal of Modern African Studies, 52, 541-570.

Spiegel, S. J. (2015a). Contested diamond certification: Reconfiguring global and national interests in Zimbabwe's Marange fields. Geoforum, 59, 258-267.

Spiegel, S. J. (2015b). Shifting formalization policies and recentralizing power: The case of Zimbabwe's artisanal gold mining sector. Society and Natural Resources, 28, 543-558.

Spiegel, S. J. (2017). EIAs, power and political ecology: Situating resource struggles and the techno-politics of smallscale mining. Geoforum, 87, 95-107.

Swradio Report. (2007). The death of Chimanimani transfrontier conservation area. http://www.swradioafrica.com/ Documents/ChimanimaniArticle.pdf Accessed 7 Oct 2017.

Timberlake, J. R., et al. (2016). Chimanimani mountains: Botany and conservation. London: CEPF Report.

Van Amerom, M. (2002). National sovereignty and transboundary protected areas in Southern Africa. GeoJournal, 58(4), 265-273.

Van Amerom, M., \& Büscher, B. (2005). Peace parks in Southern Africa: Bringers of an African Renaissance? Journal of Modern African Studies, 43, 159-182.

Van Wyk, A., \& Smith, G. (2001). Regions of floristic endemism in southern Africa. Pretoria: Umdaus Press.

Virtanen, P. (2005). Land of the ancestors: Semiotics, history and space in Chimanimani, Mozambique. Social and Cultural Geography, 6(3), 357-378.

Wolmer, W. (2003). Transboundary protected area governance. Workshop on transboundary protected areas, 5th world parks congress, Durban, South Africa.

Yuval-Davis, N. (2006). Belonging and the politics of belonging. Patterns of Prejudice, 40, 197-214.

Thielke, T. (2008). Digging for Survival: The Gold Slaves of Mozambique. Spiegel Online. https://www.spiegel.de/ international/world/digging-for-survival-the-gold-slavesof-mozambique-a-543047.html. Accessed 15 Nov 2017.

BirdLife International (2012). Eastern Afromone Biodiversity Hotspot. https://www.cepf.net/sites/default/files/eastern afromontane_ecosystem_profile_final.pdf. Accessed 20 Sept 2017. 